\title{
The legal public-private partnership framework and policy implementation in Uganda
}

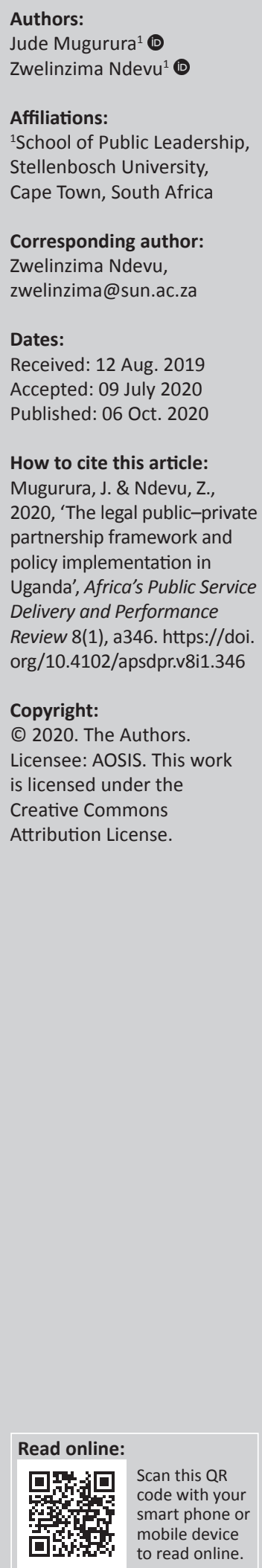

\begin{abstract}
Background: This article is based on a multidimensional empirical research study investigating aspects of the suitability of the public-private partnership environment of Uganda for road infrastructure development. The foundation of the article is the implementation of the relationship between existing legal and regulatory frameworks on the ground in Uganda.
\end{abstract}

Aim: Key aspects and realities of the legal and policy frameworks that support public-private partnership, road investment projects and programmes in Uganda are examined from the perspective of a transparent, effective and efficient service delivery.

Setting: A brief exposition of Uganda's historical realities and present challenges, especially in terms of road infrastructure, an introduction of key aspects of the legal and regulatory frameworks is presented.

Methods: The research is based on an exploratory research design methodology founded on a thorough literature review, exhaustive documentary analysis of primary and secondary sources and 30 interviews with senior and middle managers in the public and private sectors in Uganda. A semi-structured questionnaire was utilised.

Results: The analysis of data was based on a dissection of the policies and systems as foundations of solid implementation, existing legal violations, the local private sector's present conundrum and capacity gaps, the realities of integrity and corruption and the existing approach of citizens towards the problems and challenges.

Conclusion: The lack of integrity in both the private and public sector has serious negative effects on the processes, functions, planning, designing, outputs and outcomes of infrastructure initiatives undertaken.

Keywords: public-private partnerships; legal frameworks; implementation; road infrastructure; Uganda.

\section{The public-private partnership for infrastructure development}

Aigbavboa, Liphadzi and Thwala (2014:101) have stated that public-private partnerships (PPPs) have the potential of 'alleviating infrastructure backlogs in developing countries'. In a seminal work, Willems and Van Dooren (2016:203) referred to the initiative as a new and neutral procurement modality for delivering public infrastructure internationally. The process is considered as one involving greater private sector participation in terms of planning, designing, financing, constructing, operating and maintaining 'greenfield public infrastructure or operating brownfield facilities to satisfy public needs' (Alinaitwe \& Ayesiga 2013:2). This means that as a policy instrument, PPPs are instrumental in reforming procurement and service delivery for public agencies to leverage from private sector resources and efficiencies (Farquharson, Torres de Mästle \& Yescombe 2011; Yakubu \& Anigbogu 2016:61). On the contrary, private sector companies collaborate with the public sector, especially in difficult business times, such as in cases of credit market failures and stock market downturns (Hodge 2004:11).

Public-private partnerships have surfaced as a 'replacement of the active state with an enabling state' from the beginning of the 1990s and the initial successes that led to their spreading especially in the development of public infrastructure. This was described at the time as a panacea to the public sector's perpetual fiscal constraints, and the ever-increasing changes and transitions of the state, especially after the collapse of the 'Soviet bloc'. The changes in thinking, planning and implementing in that period were based on significant reforms in state management in terms of public service delivery, as state departments ceased to be 'owners', 'planners' and 'operators' of the public and were transformed into procurers of services through long-term agreements and 
contracts from the private sector founded on clearly stipulated duties and responsibilities of each party (Kalpana 2014b:5; Reim 2009:2).

As a result of its international and African expansion, as well as its diverse realities facing both state and the private sector in terms of their planning and implementation, a much expanded literature has been developed and many questions have been raised throughout the world, both conceptually and empirically. This is despite the fact that there are common elements in PPPs throughout the world as there are indeed benchmarks and standards.

A PPP has been described as a form of structured cooperation between public and private parties in a continuous process of planning, agreement and signing thereof on construction and/or infrastructural facilities. In this process, the parties relocate or share costs, benefits, risks, responsibilities and resources, and responsibilities with regard to a particular project (Koppenjan 2005:137).

A number of researchers and practitioners have criticised Koppenjan's (2005) definition as being function-specific as it has disregarded 'informal and long-term relationships' between the parties. It is also weak in the sense that it fails to draw a line between visions, values and inter-organisational objectives, within the parties' policy networks (Brinkerhoff \& Brinkerhoff 2011:3; Hodge \& Greve 2007:546).

However, a school of thought supporting Koppenjan's (2005) definition and analysis produced theory and research that strengthened his analysis. Zhang et al. (2015:499) described PPP as a long-term contractual arrangement founded on the cooperation, synergy and coordination of investors, contractors, government, and all other stakeholders and roleplayers who are directly and indirectly involved in the organisational and institutional environment, including all organisational structures and processes in the operational cycle of a specific development. Such agreements and processes are normally based on long-term contracts, which in most cases are a prerequisite for solid PPP arrangements.

One of the most accepted definitions of PPPs internationally has been advanced by Farquharson et al. (2011:11), who have described them as long-term contracts between a state institution or entity and a private firm. In this relationship, the private sector entity undertakes to plan, design, build, upgrade or expand the public sector infrastructure for which it will receive a financial return whilst assuming a number of risks. The relationship would be based on a thoroughly structured contract signed by both parties after negotiations between themselves and other key stakeholders and role-players.

One of the first original contributions to the PPP debate identified is the significance of cooperation between the parties, which ought to be based on the best expertise of each partner in their efforts to deliver clearly defined developmental initiatives (Grant 1996, cited in Alinaitwe \& Ayesiga 2013:2).
The above perspective and understanding continued in the works of Kalpana (2014b:17) and Roberts and Siemiatycki (2015:781), who believed that the key issue in any partnership oratory is the existence and maintenance of 'collaborative advantage'. The principle is based on the understanding that individuals from different organisations and disciplines must work together in order to achieve outcomes that cannot be realised in the absence of combined efforts. This means that successful PPPs enable accessibility to important resources, such as money, materials, existing information and communication, technical and managerial skills, contacts and existing relationships, legitimacy, credibility and political support, that guarantee the achievements of public service objectives (Brinkerhoff \& Brinkerhoff 2011:4).

A large number of PPP critics have advanced the belief that despite governments' recognition of the fact that there is a need for common cooperation and commitment in their PPP policy documents, in reality the private PPP partners are in most cases not allowed to become innovative beyond the explicit contract provisions (Roberts \& Siemiatycki 2015:781-782; Teisman \& Klijn 2002:204), whilst the contractual interdependence between the parties is seriously minimised (Hodge \& Greve 2017; Teisman \& Klijn 2002). Such realities result in the loss of flexibility at all operational levels (Boardman et al. 2015).

As PPPs are by nature and necessity long-term commitments on the part of all partners, effective, open and honest behaviour is vital to their success (Bovaird 2004:200; Hodge \& Greve 2007). The upholding of such behaviour and partnership is based on mutually agreed objectives, common understanding on dispute resolution agreements and measuring, assessing and monitoring, and evaluation criteria.

It can be realised thus that within this context Zhang et al. (2015:498) stated the importance of the integration of key functional and contractual perspectives as fundamental to the success of PPPs. In this sense, formal and legal dimensions of the relationship are the foundations upon which the partnership flourishes.

Commitment, trust and mutuality are the root of the social dimension of the relationship, whilst the function-specific perspective is task oriented and founded on planning, designing, financing, constructing and operationalising.

All these are a part of a perpetual dialogue amongst partners or potential partners that agree on continuous interaction, common responsibilities at risk, competitive and honest dialogue, common decisions on contractual obligations, encouragement on innovative practices and implementation, institutional and organisational arrangements and deadlines, and financial and economic mechanisms.

\section{Uganda: A brief historical overview and the present challenges}

Uganda is geographically situated in East Africa and is primarily a landlocked country covering an area of 
$241550.7 \mathrm{~km}^{2}$. It borders a variety of countries with serious political, economic and social differences, such as Kenya, South Sudan, Tanzania, Rwanda and the Democratic Republic of Congo.

Over the years, with regard to the social welfare and economic growth, there have been significant positive changes in the country. According to the latest available statistics, poverty has been significantly reduced over the years, from 56\% in 1993 to $31.8 \%$ in 2016 or $19.7 \%$, depending on different international standards in dollar terms by 2016 (Ggoobi 2016:8; World Bank 2017:21-22), whilst life expectancy jumped from 50.5 to 64.3 years for women and 45.7 to 60.3 years for men between 1991 and 2015 (World Health Organization 2017).

These achievements occurred whilst Uganda's gross domestic product (GDP) stood at about 7\% for the 2017/2018 financial year (Ggoobi 2016:7; National Budget Speech F/Y 2018/2019; World Bank 2017:42).

Despite these steps forward in terms of social and economic outlook throughout the decades, the dilemmas and realities of a key element of sustainable development, public infrastructure has not been given the priority that it deserves. This reality can be realised by the existence of a financial and investment budget of US $\$ 1.4$ billion annually (approximately $6 \%$ of the annual budget).

This has been exacerbated by the loss of approximately US\$300 million in inefficiencies evident in infrastructure and US\$1.2bn in transport costs per annum (Kyamugambi 2017:27; World Bank 2017:22 \& 24).

In comparative terms, the country underperforms at around $50 \%$ for the best and $25 \%$ for average performing economies in relation to receiving public investment, respectively (Roehler et al. 2017:10).

Given the commitment of the government towards the transformation of Uganda from a 'peasant to a modern and prosperous society by 2040', it becomes evident that the country's efforts for an expanded and sustainable public infrastructure, and especially road infrastructure, are urgent; in this regard, commitment from investors, government and all stakeholders will be invaluable for the creation of a wide alliance spearheading the vision and mission.

\section{The need for infrastructure in Africa in general and Uganda in particular}

In the seminal review of a number of empirical studies that included African countries, Byamugisha and Basheka (2016:2) concluded that the quality and net volume of physical infrastructure over the years have positively affected economic and social growth. Their research supported empirically the findings of Tripathi and Gautam (2010:135), who showed that road infrastructure has led directly and indirectly to high levels of sustainable development. Tachiwou and Hamadou (2011:132) empirically verified the fact that countries that have constructed, maintained and expanded their road and other physical infrastructure witnessed their economic growth and social welfare improving substantially.

Despite the fact that throughout the African continent roads are the main means of transport, there is a huge road infrastructure deficit as stated by Ondiege, Moyo and Verdier-Chouchane (2013:82-83). It was calculated that $52.8 \%$ of Africa's road network was unpaved, a reality which shows that access to most social services is extremely difficult.

The most recent report by the World Bank (2014) indicated that in Uganda, the road subsector is the most dominant transport mode. It carries over $90 \%$ of the country's passenger and freight traffic and is the only transport means for semirural and rural communities.

Because of the understanding of these transport and social realities and their immense contribution to economic development, the country's government set infrastructure development, and especially road development, as a key priority in terms of budget allocations.

This has become evident in the analysis of the budgetary increases for the financial years from 2014/2015 to 2018/2019, which increased by $15.9 \%$ in the first, $18.2 \%$ for the second, $18.7 \%$ for the third, $20.8 \%$ for the fourth and $20.3 \%$ for the last financial year.

The figures indicate that the transport sector remains the key budgetary item; approximately $87 \%$ of the transport sector budget has been channelled to the development and maintenance of roads (Ministry of Works and Transport Sector Budget Framework 2018 Paper F/Y 2017/18:1-2).

Whilst the efforts for infrastructure improvement have continued, the reality remains that most of the road infrastructure continues to be unaffordable, costly, substandard, unsatisfying, inaccessible and with high levels of travel time and accidents (Muhwezi \& Ahimbisibwe 2015:77; World Bank 2014).

\section{The public-private partnership legislative and regulatory framework in Uganda}

The legislative and regulatory framework of Uganda has been comprehensive in terms of road development, beginning with articles 178 (9b) and 189 (16A) of the country's Constitution as amended in 2005. The document supports PPPs as key in the alliance between the private and public sectors, working as enablers of protecting people's rights and extending equal and balanced development opportunities to the country's population in both rural and urban areas (Republic of Uganda [1995]2005:17 xi-xii). 
The Public-Private Partnership Policy of 2010 (Republic of Uganda 2010) is the foundation policy regarding PPPs and the responsibilities of the parties involved (Republic of Uganda 2010:5). The role of the private sector is dissected in relation to guidelines, regulations standardisation of PPP documents and processes, as well as capacity-building programmes. It provides the framework for public agencies and departments to assess projects, identify the appropriate private partners, negotiate the contracts and assess, monitor and evaluate their implementation.

The policy streamlines PPP accountability and procurement practices and is applicable to all public entities, including all government departments and ministries, local authorities and all statutory bodies (Republic of Uganda 2010:4). It identifies all steps to be followed in the PPP process until its finalisation, thus ensuring that it delivers a higher value for money outcome compared to conventional procurement (Republic of Uganda 2010:7-8).

Key issues identified and analysed in the law are evidence of public consultation, awareness and input as the foundations of project ownership and consensus. These participatory mechanisms include service users, staff, employees and their union representatives and public servants (Republic of Uganda 2010:10-11).

The Public-Private Partnership Act of 2015 (PPP Act) (Republic of Uganda 2015a:Section 2) is the legal foundation of all PPP projects planned and implemented under the country's National Development Plan and its key priorities.

Such projects concentrate on the development of public infrastructure through a number of strategic and operational activities, such as designing, financing, building and operating agreements; concessions; leasing, developing and operating agreements; operation and maintenance agreements; as well as building ownerships (Republic of Uganda 2015a:Sections 38-45).

The PPP Act is clear with respect to how issues related to risk management and allocation, financing technicalities and operating impacts can be dealt with through carefully structured procedures and regulations, especially through the operationalisation of stakeholder management and the description and highlights of the important responsibilities for the key PPP stakeholders (Republic of Uganda 2015a: Section 37).

The enactment of Public Finance Management Act 2015 (PFMA) rendered the outdated Public Finance and Accountability Act 2003 (PFAA) obsolete (Republic of Uganda 2015b:Section 84).

The significance of the new Act lies in the fact that it has led to the foundation for a clear, well-researched and widely accepted treatment of the basis of PPP principles with regard to agreements between parties in terms of grants and management of guarantees, auditing and accounting of public funds and public debt.
Public-private partnerships mainly occur because governments cannot afford major infrastructure developments; hence, the duties and responsibilities, the agreements on grants financing and external borrowing need to be legally binding in terms of duties, responsibilities and obligations of the parties, including government guarantees, regulations and control of processes and structures (EU 2016:5).

Thus, Section 42 (3) of the PFMA 2015 (Republic of Uganda $2015 b)$ stipulates that all financial liabilities of the state should be managed within the context of medium-term debt management strategy, clear-cut objectives, fiscal responsibility and the National Development Plan.

There are clear-cut responsibilities in the Act to be undertaken when the state is responsible in managing loans and monetary grants that have been received for a specific development (Republic of Uganda 2015b:Section 43[2] \& 44 [1\&2]). The Minister of Finance is the state authority responsible for approving monetary grants, loans and guarantees of issues (Republic of Uganda 2015b:Section 36[1]).

These clauses clearly indicate that the Act dictates strict controls, as well as accounting and auditing procedures and controls aimed at protecting from corruption, mismanagement, fraud and embezzlement (Republic of Uganda 2015b:Section 46[3g] \& 48[2]).

The Act provided a comprehensive account with respect to the management of public funds, grants, debts and guarantees (Republic of Uganda 2015b:Sections 36-44 \& 45-54), whilst at policy level the Accountant General and the Minister of Finance oversee the accountability and management of grants, public debts and guarantees.

The Internal Auditor General provides the supervision of audit committees or officers at policy level, whilst other important players include Parliament, the Secretary of the Treasury, the Auditor General, and the Audit Committees.

There are a number of key units instrumental in the implementation of the legislation, led by the Public-Private Partnership Unit (PPPU) situated in the National Department of Finance, Department of Project Analysis and PPP. Its mission is to provide the financial, technical and legal directives to all PPP committees, sections and centres (Republic of Uganda 2015a:Section 11[1a\&b]).

It provides guidance to civic education initiatives to promote PPP awareness and understanding, as well as capacity-building initiatives; advisory services; meticulous record-keeping; guidelines formulation and documentation; risk management constraints, procurement processes legal conformity, research and information analysis; efficient systems in all facets of the PPP process; and monitoring and evaluation of planning, implementing and budgetary systems within the relevant offices of the Ministry of Finance (Republic of Uganda 2015a:Section 11[2]). 
The Public-Private Partnership Committee consists of public and non-public officers, including general and permanent secretaries from relevant departments (Prime Minister's Office, Finance, Local Government and Lands), a representative from the National Planning Authority (NPA) and the Director of the PPP Unit.

The non-public officers include representatives of academics, a retired judge, the Private Sector Foundation and the Uganda Investment Authority (Republic of Uganda 2015a:Section 5). Non-public officers serve for 5 years on the committee; there is no time limit for public officers. Their services are at the discretion of the Minister of Finance in consultation with the Public Service Commission (Republic of Uganda 2015a:Sections 5c \& 6).

The committee has the power to formulate PPP policies and ensure that all legal aspects are followed; deal directly with issues of guidelines, procedures and standards for all tender awards; provide authorisation of funding; and approve plans, proposals and allocations through the review of legal, institutional and regulatory frameworks (Republic of Uganda 2015a:Section 7). These can be performed by subcommittees when necessary (Republic of Uganda 2015a:Section 9).

\section{Methodology}

An exploratory research design methodology was used in this study as it necessitates the qualitative method and approach (Strydom 2014:152153). The key methods utilised in the research process included document analysis of primary and secondary sources, interviews and a thorough literature review. A theoretical sampling method was utilised for the document analysis and the literature review in order to determine the appropriate documents available (Coyne 1997:625), whilst a purposive sampling method was used for the selection of the interviewees (Polit \& Beck 2010).

Thirty senior and middle managers from the public and private sectors in Uganda were selected and interviewed through a semi-structured questionnaire. All of them were selected as they had experience and knowledge of PPPs and had worked in such projects.

The first-hand information and data gathered from the documentary study were analysed manually through the utilisation of the systematic analysis approach. The Atlas TI software was used as the basis of the content analysis undertaken in the process.

The data collection and analysis were rooted in both inductive and deductive reasoning, as well as axiological, ontological and epistemological research philosophies. Following the completion of the interviews, the transcribed manuscripts were examined by the interviewees for authenticity. Anonymity and confidentiality were guaranteed to all participants.

\section{Analysis of data}

The fundamental empirical questions to be answered were related to the suitability of the existing legal and policy PPP frameworks that support PPP road investment projects and programmes in Uganda and on the ground implementation, with emphasis on the existing strengths and weaknesses they face.

Within this context, the research attempted to establish whether the government has established a robust PPP framework that has been supported by competent, wellestablished and resourced institutions and their existing capabilities in their efforts to effectively implement existing and future endeavours.

\section{Policies and systems as foundations of solid implementation}

There was a general agreement amongst all selected groups of respondents that there were evident weaknesses in policies and systems in the PPP terrain, especially in terms of the enforcement of local content, and serious laxity in terms of effecting restrictions for foreign labour. Uganda has a number of local content policies promoting the use of local labour, goods and services.

This is despite the fact that key legislation and policies, such as the National Development Plan II (NDP II) and key sections of the Public Procurement and Disposal of Public Assets (PPDA) Act of 2003 as amended in 2014, have been enforcing reservation and preference schemes that have been supplemented by the PPDA guidelines for reservation schemes adopted in 2018.

These realities have a direct and indirect negative effect on the use of local private sector labour, thus remaining a very serious challenge because of the law enforcement by the state of its very own legislation. Within this context, there has been a strong opinion that the state authorities have not shown a serious interest in processes affecting existing competencies within the state-managed component of PPP relationships. This can be proven to be detrimental in the planning and implementation processes (Interviewee 1, 11:14).

Added to such dilemmas is the fact that Uganda has local capacity problems in the public sector as agreed by the majority of respondents; the state's insistence on leaving key PPP processes in the hands of the private sector, including assessment and determining the dynamics and composition of foreign labour (Interviewee No. 10, 6:35), exacerbates the problems. It has been recorded that in the case of Chinese companies associated with infrastructure PPP projects, Chinese labourers perform the most elementary services such as holding flags to direct traffic or guarding the gate (Interviewee 2, 25:42).

Findings showed that processes leading to the formation of a company specifically for a PPP project are very problematic, 
especially with regard to Section 20 (1) of the PPP Act (2015), stipulating that a private party involved in PPPs must be a special-purpose vehicle (SPV) company that has been incorporated under the country's laws. Internationally, such processes are tedious and complicated in terms of compliance, and in Uganda the situation is worse because of the fact that there is a lack of a private sector that is well organised, mature, knowledgeable and coordinated.

\section{The legal violations}

Over the years, there have been a series of procurement obstructions and budgetary constraints that have resulted in slow development of the road infrastructure (Ministry of Finance, Planning and Economic Development [MFPED] 2015). Research has shown that there are multiple reasons that have been barriers to development over the years. These include mismanagement of funds that led to perpetual requests for additional funding, as well as payments for services never completed (Office of the Auditor General [OAG] Annual Reports 2010, 2011); abandonment of work and poor workmanship and tender awards to incompetent contractors or construction firms having multiple running contracts with both the Uganda National Roads Authority (UNRA) and local government entities (Uganda Debt Network 2013); serious delays in the process of awarding contracts because of non-compliance, administrative reviews and a plethora of subsequent court cases (Ministry of Works and Transport [MoWT] 2015; Public Procurement and Disposal of Public Assets Authority [PPDA 2014]; Uganda National Roads Authority [UNRA] 2014); corruption scandals such as the loss of UGX 18bn in the 2014/2015 financial year and the corrupt spending of UGX 800bn meant for the construction of Entebbe-Zana Express highway, the MukonoKatosi, Kawempe-Kafu and the Kanoni-Sembabule roads, respectively (Uganda National NGO Forum 2015); and low absorption of funds and inadequate funding allocated for the development of road infrastructure (Achola 2016:1-12).

Empirical research has shown that serious problems in the procurement structures, functions and processes have negative repercussions for the country's road development (Bogere et al. 2014:35). It has been shown that over the years the country has lost more than UGX 300bn because of malpractices and corruptions in the procurement process (Global Witness 2010, cited in Mawejje \& Bategeka 2013:21). International research on the subject has shown that procurement bribes lead to inflated contract values between $10 \%$ and $15 \%$ (Kenny 2006:5).

\section{The local private sector conundrum}

An important study dissecting the realities of PPP implementation in the infrastructure and construction industry (Alinaitwe \& Ayesiga 2013:9) has shown that the existence and development of a solid and well-organised local private sector relies on the existence of a competent workforce that is instrumental in expansion and has a competitive edge.
The findings of the present project indicate that the country's private sector does not possess the capacity to undertake PPP tasks in Uganda. This reality is rooted in human challenges, such as capacity, workplace behaviour, company formation challenges and weaknesses, and government failures.

Expert and knowledgeable interviewees pinpointed the realities of the existing ill-disciplined labour force who commit fraud, theft and other acts of corruption, with poor work ethics, the lack to comply and general laziness. Amongst contractors there are problems regarding lack of diligence, limited commitment and shoddy work.

Despite these existing and widely accepted truths, unskilled, inexperienced and unqualified local companies respond to existing tender calls for bids (Interviewee No. 2, 23:7). There has been an escalation of corruption in procurement process as aspiring successful candidates deliver substandard work in most cases (Interviewee No. 9, 7:42).

Confirmed incidents of corruption include evidence of local truck drivers siphoning fuel from company vehicles during construction work (Interviewee No. 8, 5:31) and Ugandan advising foreign contracting companies for a hefty fee (Interviewee No. 8, 18:35).

Such challenges have direct and indirect negative effects on most foreign companies operating in infrastructure projects in Uganda, including those that are sub-contracting local ones, because their trust decreases. Overall respondents agreed that there has been a more positive change of attitude amongst local workers in the past few years. The reality of daily, weekly and monthly salary and wage payments to local workers has never been commensurate with their efforts. This has a direct negative effect on the workers' attitude and morale (Interviewee No. 12, 22:53).

\section{Private sector capacity}

There is strong evidence emanating from the interviews that there are major gaps at all strategic, tactical and operational levels of the local private sector. This is weakened further by a widespread lack of essential equipment, financial capacity, technical skills, the paucity of PPP experts, absence of organised labour groups and a very weak road construction market. The lack of key specialised competencies in terms of infrastructural development is the absence of professionals, such as hydrologists and bridge specialists (Interviewee No. 8). The realities exacerbate the road industry's lack of PPP capacity at local level.

This means that the vast majority of consultants, if not all, involved in researching, planning, designing and implementing key infrastructure initiatives are foreign firms and companies, as well as individuals (Interviewee No. 5). The local private sector's evident lack of business capacity and competencies are key weaknesses leading to slow progress in the development of infrastructure, and especially road projects, in Uganda. As Alinaitwe and Ayesiga (2013:9) 
succinctly stated, in order for the country to achieve effective PPP delivery, it is up to the Ugandan public sector to invest in talent development and management and increase the capacity-building efforts at all levels so that the development of collaborative, synchronised, well-organised and a regulated PPP can be a solid government ally in effective and efficient infrastructure service delivery.

\section{Integrity and corruption}

There has been strong evidence that the lack of integrity in the private and public sector has had serious negative effects on the processes, functions, planning, designing, outputs and outcomes of infrastructure initiatives undertaken by PPPs. An empirical study of historical and existing public supply chain and procurement problems, challenges, trends and realities in Uganda (Sabiiti \& Muhumuza 2012:2039-2040) has shown conclusively that during the 2007/2008-2010/2011 financial years, the PPDA Authority was forced to arbitrate 88 supply chain and procurement cases because of the existing evidence of issues related to incorrect application of the procurement laws, rules and regulations by public offices and bidders, lack of professionalism and unethical practices.

Recent experiences indicate that such applications and violations of the PPP law, as well as rules and regulation, in Uganda seem to follow the same patterns of behaviour. The knowledgeable interviewees painted a grim picture of the public sector characterised by a lack of creativity evident in the majority of public entities and a relentless noncompliance to all principles of professional integrity and good governance.

It is strongly believed that there is a link between the lack of creativity and the bureaucratic inflexibility of most sectoral divisions of the public sector systemic establishments. It is strongly believed that this reality is mainly attributed to the government's failure to introduce, maintain, develop and reward innovative practices. The outcome of such a governmental attitude leads to a continuous lack of commitment of public officers towards government interventions as they feel undermined.

One of the respondents narrated his personal experience of a public servant who dodges his office for a week in order to engage with his 'contacts' in the private sector (Interviewee 15). It is thought that such public servants' behaviour that has become common can not only frustrate potential investors, but also lead to a number of organisational gaps that could be associated with key sections of the service such as supply chain and procurement, internal and external audit, budgeting and risk management. Such gaps are taken advantage of through a series of unethical practices such as fraud, misappropriation and late release of funds that cause serious delays in infrastructure projects.

The organisational gaps and lack of commitment on the part of public servants have led the government to an over-reliance attitude towards the private sector, especially in terms of initiating infrastructure projects. One of the participants stated that Uganda is in a process of experiencing a bandwagon effect and just follows the example of other countries that do things because the World Bank supports and promotes an initiative. When the World Bank does it, it is considered a suitable practice for Uganda (P2, 18:5); most of the PPP project concepts have always come from the private sector themselves because government has not been proactive (Interviewee No. 6). Multilateral involvement, especially under the aegis and protection of organisations such as the World Bank, could lead to problems and challenges as recent history has taught Africa, but there is a strong belief that their participation could lead to an extension of opportunities with respect to infrastructure developments in Uganda in particular and Africa in general. For such undertakings to bear fruit, there is a need for planning, implementation, and monitoring and evaluation founded on the historical and present context of the country's situation and circumstances.

Participants provided concrete evidence that directly link public servants' corruption and bribery, as well as other instances of lack of principles of good governance that seriously compromised transparency and competition. It was repeatedly indicated that bribery and corruption in the public and private sectors perpetuate this problem, as it was stated that when someone brings in a specific project this is done not for the national interest but the 'cut' that goes with it (Interviewee No. 10). It was mentioned that private companies have over the years offered bribes to politicians and public administrators in exchange for tenders (Interviewee No. 5). The participants indicated that their personal experience taught them that competition in financing and project procurement has been a very serious challenge. In support of such a position, the KampalaEntebbe Express (KEE) Project, a 51-km toll road under the auspices of UNRA, started in 2012 with a contract awarded to the China Communication Construction Company. It was stated that contractors have never been selected through transparent and competitive international bidding. In addition, the source of financing of a number of projects has not been secured through competitive practices and processes (Interviewee No. 8). In fact, in the last decade, there is proof that foreign investors demand non-competitive practices. Chinese companies thus do not undertake infrastructure projects; they are supported by Chinese financing and road construction models (Interviewee No. 1). When the Chinese government provides loan financing for an infrastructure project, it demands that Chinese companies undertake to begin and complete it (Interviewee No. 1). Existing conditions thus undermine competition, financing, planning and organisational imperatives, as well as the true spirit and ideals of pure PPP models. It has been a common belief amongst the majority of participants that there is a lack of transparency on the part of government that is a serious barrier to competitive practices.

The government has been described as very secretive, especially amongst participants from the private sector where 
it has been revealed that when information on forthcoming PPP projects is sought from the public servants responsible, the response is always that 'the information is confidential'. The secrecy with respect to PPP contracts that are in fact public documents has become such a reality that even the country's parliamentarians beg to have access to contracts signed between the government and private sector partners (Interviewee Nos. 2 \& 8).

Empirical research (McGrath et al. 2008:16) has shown that the lack of transparency has become a universal PPP trend as it has been shown that information regarding PPPs is very difficult to obtain, even in countries that have the reputation of having a very developed freedom of expression and information tradition and culture. There is a general belief amongst the participants that secrecy in dissemination of project information could ultimately lead to strong opposition to PPP projects from the population or sections of it. This is because when secrecy becomes evident, people start guessing and speculating, and the situation becomes exacerbated when societal groups such as media, non-governmental and community-based organisations receive the wrong information about forthcoming projects (Interviewee No. 12)

\section{The citizen approach}

The general attitude amongst the citizens has been considered to be clearly dishonest with respect to PPP realities, mainly during the public attitude data collection when such projects are considered. It is generally believed by the participants that such a negative attitude is a serious hindrance to the whole process because research-based experience in the country indicates that very few people will express their true feelings, beliefs and ideas on PPP issues. This attitude is basically rooted in the lack of trust and confidence in the state institutions, the government and Uganda's public service credentials (Interviewee No. 4).

Such attitudes have direct and indirect negative consequences for effective decision-making on the part of the state as it will be relying on wrong information. This means that key issues fundamental to the success of the process of determination of viability of planning, designing and implementing a proposed PPP project are founded on wrong and false information.

\section{Conclusion}

Despite the fact that there was a general agreement amongst the participants that Uganda has a wide array of laws, rules and regulations regarding PPPs, there were a number of key reasons pointing to the problems and challenges in terms of their implementation.

One of the key reasons identified has been the chronic lack of enforcement of local content and the perpetual use of foreign labour that have not been of the highest standard. Uganda has a number of local content policies promoting the use of local labour, goods and services. The lack of law enforcement on this issue has perpetuated the serious local capacity problems in the private and public sector.

Such a situation was exacerbated by the long and tedious processes related to Uganda's laws that dictate that private sector companies involved in PPPs need to be an SPV company that has been incorporated under the country's legal system.

In addition, legal violations in the public and private sectors lead to mismanagement of funds, with such acts resulting in tender awards to incompetent contractors or construction firms and serious delays in the process of awarding contracts because of non-compliance, administrative reviews and a large number of court cases.

The mismanagement of procurement structures, functions and processes has resulted in billions of losses owing to fraud, bribes and corruptions that lead to inflated contract values.

The lack of integrity in both the private and public sector has serious negative effects on the processes, functions, planning, designing, outputs and outcomes of infrastructure initiatives undertaken by PPP as identified in official government documents that have recorded incorrect application of the procurement laws, rules and regulations by public offices and bidders, lack of professionalism and unethical practices. These are supplemented by a lack of relentless noncompliance to all principles of professional integrity and good governance and bureaucratic inflexibility of key organisational sections and sectoral divisions of the public sector systemic establishments, such as supply chain and procurement, internal and external audit, budgeting and risk management.

As bribery and corruption in the public and private sectors continue, the involvement of politicians, administrators, mediators and private sector companies has become common as shown concretely in KEE Project amongst others.

Despite the almost monopolistic position in the PPP Uganda terrain, Chinese companies have seriously undermined competition, financing, planning and organisational priorities that ought to be the ethical and professional imperatives of a professionally based and ethical PPP.

The government strategy and tactics of secrecy have been criticised by the country's private sector, but at present it seems incapable of rectifying the situation.

Adding to these realities, the weaknesses and lack of capacity of the local private sector associated with workplace behaviour, company weaknesses and failures are multiplied by an ill-disciplined existing labour force being corrupt, lacking work ethics and compliance. 
Such realities amongst local workers result in negative effects on most foreign companies operating in infrastructure projects in the last few years.

The local sector, on the other hand, has over the years suffered because of the lack of strong and innovative strategic, tactical and operational levels and is further weakened by a wide array of functional imperatives, such as the lack of PPP experts, financial capacity, essential equipment, technical skills and the absence of organised labour groups, hydrologists and bridge specialists. These facts lead to the almost complete control of the lucrative market for foreign companies.

The need for more infrastructure development in Uganda in particular and Africa in general is at present in the hands of governments and foreign businesses, financing and labour. The key question is, 'is this the ideal solution to infrastructure problems?' Time will tell.

\section{Acknowledgements Competing interests}

The authors have declared that no competing interests exist.

\section{Author's contributions}

All authors contributed equally to this work.

\section{Ethical consideration}

This article followed all ethical standards for carrying out a research without direct contact with human or animal subjects.

\section{Funding information}

This research received no specific grant from any funding agency in the public, commercial or not-for-profit sectors.

\section{Data availability statement}

Data sharing is not applicable to this article as no new data were created or analysed in this study.

\section{Disclaimer}

The views and opinions expressed in this article are those of the authors and do not necessarily reflect the official policy or position of any affiliated agency of the authors.

\section{References}

Achola, I., 2016, A review of Uganda's road fund proposals for transformation, ACODE, Kampala.

Aigbavboa, C.O., Liphadzi, M. \& Thwala, W.D., 2014, 'An exploration of public private partnership in infrastructure development in South Africa', in S. Laryea \& E. Ibem (eds.), Proceedings of the 8th Construction Industry Development Board (CIDB) Postgraduate Conference, Johannesburg, South Africa, February 10-11, 2014, pp. 101-109.

Alinaitwe, H. \& Ayesiga, R., 2013, 'Success factors for the implementation of publicprivate partnerships in the construction industry in Uganda', Journal of Construction in Developing Countries 18(2), 1-14.
Boardman, A.E., Greve, C. \& Hodge, G.A., 2015, 'Comparative Analyses of Infrastructure Public-Private Partnerships', Journal of Comparative Policy Analysis: Infrastructure Public-Private Partnershiph and Practice 17(5), 441-447.
Research

Bogere, G., Kabasweka, F.G., Kayabwe, S. \& Achola, I., 2014, Assessing public expenditure governance in Uganda's road sector application of an innovative framework, viewed n.d., from https://media.africaportal.org/documents/PRS_66.pdf

Bovaird, T., 2004, 'Public-private partnerships: From contested concepts to prevalent practice', International Review of Administrative Sciences 70(2), 199-215. https:// doi.org/10.1177/0020852304044250

Brinkerhoff, D.W. \& Brinkerhoff, J.M., 2011, 'Public-private partnerships: Perspectives on purposes, publicness, and good governance', Public Administration and Development 31(1), 2-14. https://doi.org/10.1002/pad.584

Byamugisha, A. \& Basheka, C., 2016, 'Measuring the performance of the economic infrastructure and competitiveness cluster in Uganda', Journal of Public Administration and Policy Research 8(1), 1-11. https://doi.org/10.5897/ JPAPR2015.0319

Coyne, I.T., 1997, 'Sampling in qualitative research. Purposeful and theoretical sampling; merging or clear boundaries?', Journal of Advanced Nursing 26(3), 623-630. https://doi.org/10.1046/j.1365-2648.1997.t01-25-00999.x

European Union, 2016, Contribution to the African Investment Facility, in Support to Further Development of the Northern Corridor Road Axis in Uganda- KampalaJinja Expressway (CRIS number: UG/FED/039-115), viewed n.d., from https:// europa.eu/european-union/index_en

Farquharson, E., Torres de Mästle, C. \& Yescombe, E.R., 2011, How to engage with the private sector in public-private partnerships in emerging markets, The World Bank, Washington, DC.

Ggoobi, R., 2016, 'Performance of Uganda's economy: Progress, opportunities, challenges and the way forward. An independent assessment of Uganda's economy', A presentation at the NRM MPs-Elect Retreat, 12th-20th March 2016 at the National Leadership Institute (NALI), Kyankwanzi.

Global Witness, 2010, Donor engagement in Uganda's oil and gas sector: An agenda for action, viewed 13 March 2019, from http://www.globalwitness.org/sites/ default/files/pdfs/uganda_final_low.pdf

Hodge, G.A., 2004, 'The risky business of public-private partnerships', Australian Journal of Public Administration 63(4), 37-49. https://doi.org/10.1111/j.14678500.2004.00400.x

Hodge, G.A. \& Greve, C., 2007, 'Public-private partnerships: An international performance review. Essays on service delivery and privatization', Public Administration Review 67(3), 545-558. https://doi.org/10.1111/j.1540-6210. 2007.00736.x

Hodge, G.A. \& Greve, C., 2017, 'On public-private partnership performance: A contemporary review', Public Works Management \& Policy 22(1), 55-78. https://doi.org/10.1177/1087724X16657830

Kalpana, G., 2014a, Public private partnerships. A study in organizational design, viewed 04 April 2019, from http://dx.doi.org/10.2139/ssrn.2382648

Kalpana, G., 2014b, Public private partnerships. A comprehensive survey of literature, viewed 22 February 2020, from https://www.academia.edu/6186801/ Dr_Kalpana_Gopalan_IAS_PhD_PUBLIC_PRIVATE_PARTNERSHIPS_A_ COMPREHENSIVE_SURVEY_OF_LITERATURE_23̄_02_2014

Kenny, C., 2006, Measuring and reducing the impact of corruption in infrastructure, vol. 4099, World Bank Publications, Washington, DC.

Koppenjan, J.F.M., 2005, 'The formation of public-private partnerships: Lessons from nine transport infrastructure projects in The Netherlands', Public Administration 83(1), 135-157. https://doi.org/10.1111/j.0033-3298.2005.00441.x

Kyamugambi, K., 2017, 'The Patriot Uganda's leading independent business magazine', $1(12)$, n.p.

McGrath, F.B., Cisarova, E., Eger, A., Gallop, P., Kalmar, Z. \& Vera, P., 2008, Never mind the balance sheet: The dangers posed by public-private partnerships in Central and Eastern Europe, CEE Bankwatch Network, viewed 05 May 2018, from http:// www.bankwatch.org/documents/never_mind the balance_sheet.Pdf

Ministry of Finance, Planning and Economic Development, 2015, 'Republic of Uganda: The State of Public Service Delivery in Uganda. Achievements, challenges and measures for better service delivery', paper presented at the National Budget Conference for FY 2016/2017, Serena International Conference Centre, Kampala, 11 June.

Ministry of Works and Transport (MoWT), 2015, 'Sustainable transport infrastructure development and utilization: An engine for economic transformation', in The 11th Joint Transport Sector Review Workshop Presentations, September 16th-17th, Hotel Africana, Kampala.

Ministry of Works and Transport (MoWT), 2018, Sector Budget Framework Paper FY 2017/2018, Republic of Uganda, Government printers, Kampala.

Muhwezi, M. \& Ahimbisibwe, A., 2015, 'Contract management, inter functional coordination, trust and contract performance of works contracts in Ugandan public procuring and disposing entities', European Journal of Business and Management 7(20), 76, 86.

National Budget Speech F/Y, 2018/2019, 'Republic of Uganda: Industrialisation for job creation and shared Prosperity', Delivered by Minister of Finance, Planning and Economic Development at the 3rd Session of the 10th Parliament of Uganda, 14th June, 2018.

National Development Plan (NDPII), 2015/16-2019/20, 'Republic of Uganda', in Strengthening Uganda's competitiveness for sustainable wealth creation employment and inclusive growth, June 2015, Government printers, Kampala.

Office of the Auditor General, 2010, 'Republic of Uganda', in Annual report of the Auditor General for the year ended 30th June 2010, Value for money audit, vol. 5, Government printers, Kampala. 
Office of the Auditor General, 2011, 'Republic of Uganda', in Annual report of the Auditor General for the year ended 30th June 2011, Value for money audit, vol. 5, Government printers, Kampala.

Ondiege, P., Moyo, J.M. \& Verdier-chouchane, A., 2013, 'Developing Africa's infrastructure for enhanced competitiveness', The Africa Competitiveness Report 2013, pp. 69-92.

Polit, D.F. \& Beck, C.T., 2010, Essentials of nursing research: Appraising evidence for nursing practice, Lippincott Williams \& Wilkins.

Public Procurement and Disposal of Public Assets Authority, 2014, Republic of Uganda: Procurement and disposal audit report of Uganda national roads authority for the financial year 2011/12, viewed n.d., from https://www.ppda. go.ug/

Reim, C., 2009, 'Challenges to public private partnerships. The example of the London underground PPPs', Unpublished doctoral dissertation, University of Potsdam

Republic of Uganda, [1995]2005, Constitution of the Republic of Uganda, Government printers, Kampala.

Republic of Uganda, 2010, Public private partnership policy 2010, Government printers, Kampala.

Republic of Uganda, 2014, Public procurement and Disposal of Public Assets Act of 2003 (as amended 2014), Government printers, Kampala.

Republic of Uganda, 2015a, Public Private Partnership Act 2015, Government printers, Kampala.

Republic of Uganda, 2015b, Public Finance Management Act, Ministry of Finance, Planning and Economic Development 2015, Government printers, Kampala.

Roberts, D.J. \& Siemiatycki, M., 2015, 'Fostering meaningful partnerships in publicprivate partnerships: Innovations in partnership design and process management to create value', Environment and Planning C: Government and Policy 2015(33) 780-793. https://doi.org/10.1068/c12250

Roehler, C., Charaoui, J., Darcy, M., Khasiani, K. \& Navarro, A., 2017, Enhancing the performance of public investment management for Uganda, Technical assistance Report, IMF Country Report No. 17/269, The International Monetary Fund, Washington, DC.

Sabiiti, C.K. \& Muhumuza, E., 2012, Second generation procurement, moving from compliance to results in public procurement: Trends, challenges \& opportunities from the Uganda experience, viewed 19 April 2018, from http://www.ippa.org/ IPPC5/Proceedings/Part7/PAPER7-14.pdf

Strydom, H., 2014, 'An evaluation of the purposes of research in social work' Social Work/Maatskaplike Werk 49(2), 149-164. http://dx.doi.org/10.15270/ 49-2-58
Tachiwou, A.M. \& Hamadou, O., 2011, 'Infrastructure development and economic growth in Togo' International Journal of Economics and Finance 3(3), 131-138. https://doi.org/10.5539/ijef.v3n3p131

Teisman, G. \& Klijn, E.H., 2002, 'Partnership arrangements: Governmental rhetoric or governance scheme?', Public Administration Review 62(2), 197-205. https://doi. org/10.1111/0033-3352.00170

Tripathi, S. \& Gautam, V., 2010, 'Road transport infrastructure and economic growth in India', Journal of Infrastructure Development 2(2), 135-151. https://doi. org/10.1177/097493061100200204

Uganda Debt Network, 2013, Civil society position on key issues in procurement: Advocating for improved public accountability and service delivery in Uganda, Kampala, Paper issue No.2, pp. 1-22. viewed n.d., from https://www.udn.or.ug/index.php/resources/ udn-policy-reports/165-key-issues-in-procurement-processes-in-uganda/file

Uganda National NGO Forum, 2015, Roads funds theft. Citizen action against theft of our money without SHAME, The Black Monday Movement Bulletin, Kampala.

Uganda National Roads Authority, 2014, Effect of procurement procedures and project implementation on resource absorption. Experiences of the Road Sector in Umplementation on resource absorption. Experiences of the Road Sector in Authority, Kampala, 20th February 2014.

Van Doeveren, V., 2011, 'Rethinking good governance: Identifying common principles', Public Integrity 13(4), 301-318. https://doi.org/10.2753/PIN10999922130401

Willems, T. \& Van Dooren, W., 2016, '(De) Politicization Dynamics in Public-Private Partnerships (PPPs): Lessons from a comparison between UK and Flemish PPP policy', Public Management Review 18(2), 199-220.

World Bank, 2014, International development association project appraisal report to the Republic of Uganda for a North Eastern Road-Corridor Asset Management Project Transport Sector Country Department, AFCE1 Africa Region, Washington, DC.

World Bank, 2017, Infrastructure finance deficit: Can public-private partnership fill the gap? Uganda's Economic Update, 9th edn., May 2017, Washington, DC.

World Health Organisation, 2017, Country cooperation strategy at a glance for Uganda, viewed 24 December 2017, from https://apps.who.int/iris/bitstream/ handle/10665/136975/ccsbrief uga_en;jsessionid=AF2D391F622714F6A2D8102 E1F4B73B2? sequence $=1$

Yakubu, S.N. \& Anigbogu, N.A., 2016, 'A conceptual framework for managing risks in public private partnership projects in housing estate development in Nigeria', International Journal of Regional Development 3(1), 50-63. https://doi.org/ 10.5296/ijrd.v3i1.8144

Zhang, S., Gao, Y., Feng, Z. \& Sun, W., 2015, 'PPP application in infrastructure development in China: Institutional analysis and implications', International Journal of Project Management 33(3), 497-509. https://doi.org/10.1016/j. ijproman.2014.06.006 